\title{
Differentiating Scholarly Generations: On Hitler's child soldiers, 60's Revolutionaries and Forgotten Connections
}

\author{
Alex Aßmann, University of Göttingen, Germany \\ alex.assmann@sowi.uni-goettingen.de
}

In December 1986, ${ }^{\mathrm{i}}$ three years after the appearance of Forgotten Connections - with a second German printing and a Dutch translation already out - its 57-year old author, Klaus Mollenhauer, sat down with Theodore Schulze and a handful of selected colleagues in Tübingen. They had gathered for a colloquium, an inter-generational conversation, in order to capture their perspectives in an edited collection (Kaufmann/Lütgert/Schulze/Schweitzer, 1991). These circumstances granted the gathering a particular atmosphere of openness, even intimacy.

Initially Mollenhauer and Schulze held an open conversation on the former's biography, followed by a discussion on salient points brought up by the rest of the group. Whether all of the participants named in the collection were actually present at this conversation is uncertain. But, by simply looking at a listing of the participants at the Tübingen colloquium in, an interesting image emerges of direct interactions between representatives of different "generational locations", to reference Karl Mannheim (1928).

A study of the dynamics of these discussions - my principle task in this short essaymakes it clear how those present articulate quite different life courses, based on their varying birth years. To borrow two further ideas from Mannheim, they give expression to particular "generational context," showing the formation of their own "generational unity".(Mannheim, 1928 , p. 541) The younger, in this case, those who were later called "68er's," clearly differentiated themselves from those slightly older, the 45-er's; those who had been forced in their childhood or youth to serve as Hitler's "child soldiers," or more specifically, as "air-defense helpers" (hereafter Flakhelferii) in the desperate final days of the war.

I would like to show how Klaus Mollenhauer (born in 1928) articulated his own generational location or position in his dialogue with Schulze, while those present whom identified with the events of 1968 used the same discussion to delimit their own generational location. Forgotten Connections plays, at first glance, only a very marginal role. However, the positions of the participants become increasingly significant, particularly, the younger generation's identification with a disciplinary paradigm developed from the critical theory of the Frankfurt School. This was the condition of the possibility of the coalescence of an entire generation of educational scholars. Or, in other words: The disciplinary formation and identity of education, its very existence as a field, was seen as dependent on its relationship to critical theory.

\section{Location, Context, Units and the 'Problem of Generations'}

A helpful starting point for assembling an individual and professional biography in the complex social and professional context German academe is provided by the concept of the "generation." 
"Generational location" can be initially understood simply in terms of successive cohorts of those sharing the same birth-year, making those from a given year or set of years a "generation." This is especially true insofar as they were born into a comparable milieu, and were subject to similar influences in their early, impressionable years. In short, they are party to the same or similar historically determined experiences.

Mannheim uses the term "generational context" to refer to commonly held, historically shaped dispositional structures developed during the formative years of those sharing one or a small cluster of birth years. Within a single generational context, a number of "generational units", intra-generational differentiations can emerge, according to Mannheim. This happens when members of the same generation sharing common experiences, but arrive at different conclusions from them. "Generational units can be recognized through the actions of the members of a common generational context" (Bebnowski, 2012, p. 18), as David Bebnowski explains.

That the importance of such generational differences was also noted by those involved in the discussion, as is made clear in the commentary introducing the discussion transcript:

The conversation between Klaus Mollenhauer and Theodor Schulze is different from the two previous discussions [or chapters in the edited collection], in that both participants belonged to the same generation, having known each other since their student days. Also the broader discussion that followed was marked by those from different generational locations. The direct teacher-student relationship between the 30 and 40 year olds and those in their 50s and 60s [at the time] expressed itself in the lively and pointed group conversation that followed. (Kaufmann et al, 1991, p. 83)

The points of contention were identified in this same commentary as "critical theory and its appropriate application in education" on the one hand; and on the other, the impression that Mollenhauer had abandoned "the concept and program of emancipation."

This expands the practical conceptualization of generations - also from a methodological-heuristic perspective - in a significant way. If Mannheim's notion of generations provides valuable structure to scholarly, disciplinary history, it follows that those involved in the discussion - not the Mollenhauer - Schulze one, but the broader one that followed - perceived their situation in terms of generational conflict. How does something like this arise? And under what conditions does it become relevant to the investigation of the history of a discipline, and of the understanding of a book like Mollenhauer's Forgotten Connections?

Mollenhauer explains his own generational positionality to Schulze initially in terms of his service as a Flakhelfer, in the last year of the war -clearly avoiding mention of the biographies of his parents, even though they are clearly an important factor in his scholarship and generational location. "Among those who were born in 1928," Mollenhauer admits, "there have been frequent discussions about whether there is a common characteristic that we share. The answer is that we were members of the Flakhelfer generation. I was 15-years old when I was drafted. We all had to leave our families, initially to defend our cities from attacks from the air, and then, in the last six months of the war, we were involved in fighting on the ground. Between our 15 th and 17 th years, we had to do something that was a radical departure from the normal life course." (Kaufmann et al., 1991, p. 69) In January of 1944, Mollenhauer was stationed to a unit that operated search-lights at a place called Schützendorf (today: Budzień, Poland) near Stettin, over $150 \mathrm{~km}$ (100 miles) northeast of Berlin. Mollenhauer was assigned the role of a 
radio operator. At that time, the area was subject to very aggressive air attacks from allied forces. Due to the German retreat in the face of the advancing Red Army, Mollenhauer was forced to defend his position, and finally ended up being captured as a prisoner of war. The Russian occupiers transferred him immediately to a British prison camp at Großenbrode on the Baltic Sea, where he stayed for seven weeks, 'till June 21, 1945. It is hard to imagine a set of circumstances confined only to his family that would have a similar impact on his sense of generational identity.

Born on October 311928 in Berlin, Mollenhauer was the first of two sons of Wilhelm (1899-1968) und Charlotte Mollenhauer (nee Schneider, 1903-1984). It is worth mentioning, anecdotally as an aside, that in their youth, both Mollenhauer's father and mother were members of musician's guild within the Wandervogel, a popular youth movement in Germany emerging at the end of the $19^{\text {th }}$ century. In an attempt to shake off the restrictions of society and "get back to nature," these youth took on this name - literally"wandering bird" - which suggests the activities in which they partook: rambling, hiking, and outdoor activities and "adventures" of various kinds; all of this in opposition to the values and standards of the modern bourgeois society.

Mollenhauer's father, Wilhelm, completed his studies in Berlin under the supervision of the famous Christian-socialist professor in social work; Carl Mennicke (also under Siegfried Bernfeld, a scholar in psychoanalysis and education ${ }^{\text {iii }) ~ j u s t ~ b e f o r e ~ K l a u s ~ w a s ~ b o r n . ~ W h i l e ~}$ Wilhelm was studying, his wife worked as a youth welfare worker. Immediately after his studies, Wilhelm went to work in Berlin as a prison pedagogue and soon became a director of similar services at a prison for youth in nearby Cottbus. Mollenhauer's father also played an important role - to be later recognized as an "opinion leader"-in the recently founded Social Work Guild, an organization that remains important in Germany today. All of this suggests that both of Mollenhauer's parents were protagonists in the professionalization of social work in the Weimar Republic, and that since his birth, Mollenhauer was immersed in a milieu in which personal agency in issues of youth and social concern were paramount. Indeed, it is telling that at the Georg-August-University in Göttingen, where Klaus Mollenhauer himself was just completing his Masters work in Philosophy under the supervision of Erich Weniger and Helmuth Plessner in 1958, his father was awarded an honorary doctorate from the Faculty of Law in 1959. So, one year before his father Wilhelm, who had to join the Volkssturm in 1945, Klaus Mollenhauer went to the war, yet in 1944. And he held his doctoral degree one year before him, as well.

\section{The Flakhelfer-Generation and the ‘68ers}

At this point, it is clear that the background of Mollenhauer's parents in youth advocacy would also play a decisive role in his own professional development. Nevertheless, Mollenhauer chose, in the conversation we are examining, to associate himself with the Flakhelfer generation, underscoring his affinity with this generational cohort, both in terms of his professional biography and of broader social, inter-generational relations. The Flakhelfer generation was once aptly characterized by literary critic Jürgen Busche as "big brothers" - a characterization which is apt precisely because it was made from the vantage point of a '68er. From this perspective, the Flakhelfer generation are big brothers, particularly insofar as the 68ers are the younger siblings. In this scenario, what the ' 68 and Flakhelfer generations have in common are parents, who were adults during the Nazis' rise to power.

The age difference separating the Flakhelfer and ' 68 generations averages out somewhere above ten years. When those only later known as '68ers were born in the final years of the war - 
or those who were even younger - were very young, as old as four or five, when the Flakhelfer (whose generational unity can be more precisely dated) were between 14 and 18. And these "big brothers" either already had very adult experiences in the war, or at least had dealt in some way with being called up for such service.

If a few among the '68ers had memories of the war, they were of nights spent in bomb shelters - of expulsion and misery. Members of this generation, however, were still too young to bring this into conscious connection with state institutions and national-socialist ideology. Rather, they were at an age at which their collective impressions were difficult to interpret in the light of other biographical norms and patterns. Although the profiles of these two generations are quite different, they share a common characteristic in terms of their parents, whose years of birth date roughly between 1880 and 1910 .

As far as their parents were concerned, concrete knowledge common to the Flakhelfer generation includes, for example, the reality that as "the synagogues burned, their parents simply [watched. They also knew that those adults] who had emphasized concepts of law and order at home or in school had failed [in some significant sense]. But these adults could not be brought, with their young pupils, in engagement with children between six and ten years, to see themselves as having led failed lives." (Busche, 2007, p. 45) Consequently, and particularly in the form of slightly older cousins and relatives, the expression "big brothers" appears particularly a propos, suggesting the cultural and sociological significance of the relation between the two generations, as it was realized around 1968 itself. This "simultaneity of the non-simultaneous" (Pinder, 1926; Mannheim, 1928), which is connected to the spatial simultaneity of contact between neighboring generations, who had experienced very different childhoods, realizes itself between the "68ers and the "big brothers" between the middle and end of the 1960's within educational institutions, and in other political movements and organizations. The reformation of the educational systems, focusing on standards as social justice, ability to be democratic and participation, as it proceeded in the 1960s, was an institutional context for the Flakhelfers as young teachers, and the generation of 1968 as their students. At the same time, anti-Vietnam demonstrations were violently subdued by the policy while the parent's generation committed itself to a more overtly anti-totalitarian consensus, which was an anti-communist consensus in fact. In other words, the federal German educational system is increasingly orientated towards the responsible, empowered citizen; while in public, social critique is suppressed. This is the background of their common experience, which the Flakhelfers and the '68ers had to share in the mid 1960s, nevertheless playing different roles. As lecturers, young politicians, writers or young teachers, the Flakhelfers had yet to become decision-makers, while the 68ers still were undergraduates, school-students or apprentices.

The context of their, perhaps most productive, instance of interconnection was, during this time, in the university. Here, the generation of ' 68 were just starting their studies, while their "big brothers" had received appointments and were active as teachers.

For the 1968 generation, this meant,

Most of the younger professors and instructors, with whom they came into contact in the $1960, \mathrm{~s}$, had earlier worked under scholars who were silent about at least some of their actions during the years of dictatorship, and did not immediately disavowed what they had earlier taught. This point of contact did not mean that the younger [in this case, the big brothers,] did not take up new directions. Also, a few of the new luminaries [from the "big brother" generation] had taken rather convoluted paths to tenured faculty 
positions, thus making the construction of simple narratives of their own lives impossible. There were among the generation of the big brothers not a just a few professors, who had produced outstanding books for their students in the 60's. Certainly Ralf Dahrendorf's Society and Democracy in Germany, Juergen Habermas' Structural Transformation of the Public sphere, and Eberhart Lämmerts' Bauformen des Erzählens (construction of narrative forms).(Busche, 2007, p. 47)

And of course, there is Mollenhauer's own book Erziehung und Emanzipation (education and emancipation), which Michael Winkler (2002, p. 50) and others have identified as "characterizing an epoch."

\section{Education and Emancipation- the Impact of a Book on the 1960s-Protest-Movement}

A programmatic character typical of these books and of the scholarship of the generation of scholars to which Mollenhauer belonged is pointedly in evidence in Mollenhauer's 1968 monograph, Erziehung und Emanzipation. Its program, like that of other texts of its era, was to be able to address the enormous complexity of modern societies:

The practical problems of education can no longer be formulated simply in terms of the given social conditions, but must be seen from the perspective of progressive democratization in opposition to these terms. In other words: An emancipatory notion of education is not "functional," but rather, dysfunctional in light of the present social system. It highlights social conflict. (Mollenhauer, 1968, p. 27)

Such a powerful formulation resonated with the student movements of the 1960's, particularly as this book was the first to highlight the value of the theory of the Frankfurt School for educational praxis.

That Mollenhauer's program in the years that followed had only limited practical impact is evidenced in the failure of educational reforms - a reality that became clear by the end of the 1970s. If education, as Herwig Blankertz said earlier, might possess a kind of "advance credit," as granted by society, then by the 1980's it was clear that this had been "gambled away". School reforms had changed very little in the existing social structures and individual's participation in them. It seemed as though the default conclusion of socialization theory, that class membership inevitably reproduces itself, had won the day. It seems that education could not, despite all of this, say something about how someone who does not fit into social structures might still play a part in society (or that the structure indeed in this way can be destabilized). This is because education was not in a position to think in terms of the categories of social theory and socialization. Its historical concepts of Erziehung (education) and Bildung, and in myriad cultural-historical associations, had forfeited these analytical possibilities.

This was Mollenhauer's complaint of at the end of the 1970s - that, during the era of reform, "questions about the Bildung had been reduced to issues of socialization," and that parallel to this tendency, another had emerged: 
The publicity of the Frankfurt Critical Theory, and the proliferation of Marxist orientations in education fostered on the one hand a ...rhetoric that sought to differentiate itself from "bourgeois" and other scholarly forms; the literature, which has appeared in this context frequently limits itself to a conceptual critique of pedagogically relevant constructions of social science, deductions about class structures or economic analyses all of which give scant if any attention to the child, and to his or her pedagogical experiences. (Mollenhauer, 1979, p. 241f.)

\section{'Forgotten Connections' and the Self-Location of a Generation}

In this connection, a small part of the conversation mentioned above, in which ChristophTheodor Scheilke and Andreas Gruschka also engage with Mollenhauer, is relevant. Gruschka was born in 1950, Scheilke in 1948, both belonging to the generation of Mollenhauer's students. In this "plenary" part of the conversation, these younger interlocutors seize upon the accusation that a text like Forgotten Connections represents an act of "infidelity" vis-à-vis critical theory. Gruschka further specifies that this accusation "has to do with two things: with a departure from school reform, and retreat from social-critique." (Kaufmann et al, 1991, p. 83). It was a foregone conclusion that Mollenhauer not only had nothing to do with critical theory, but also that he was no longer in a position to meaningfully address the issue of emancipation.

Scheilke puts this in even more dramatic terms: "I also see Mollenhauer's 'turn' as a kind of infidelity to [his figurative] adopted children who had taken on his emancipatory pedagogy." (Kaufmann et al, 1991, p. 86) What does this break with tradition mean for the young pedagogues who had earlier aligned themselves with Mollenhauer and those like him? For his part, Mollenhauer simply responds by asking: "How is one to answer to these questions in a simple conversational reply?" (Kaufmann et al, 1991, p. 86)

This answer bears traces of resignation; all the same, Mollenhauer tries to explain:

With a conception of education that only focuses theoretically on the definition of skills and knowledge demanded by the labor markets, the reservoir of questions interesting and important to pedagogy is rapidly depleted. Education would be well served by again expanding the range of questions it is willing to consider: on the one hand, to recall the concepts of (for example) Herder, Humboldt, Simmel; on the other hand, to be open to theories of cognitive development and psychoanalytic concerns. If others want to refer to changes in scholarly interest of this kind as a "turn", I will not object; but it is not a helpful label. (Kaufmann et al, 1991, p. 86)

Mollenhauer continues by playing on the way that "Bildung" and "Culture" are taken up in Forgotten Connections:

One of the things that this expanded conception of education should make us sensitive to, I think, is the paramount importance of the symbolic forms belonging to human Bildung. This is imperative for "culture" and it stands against society and economy... The 'adoptive children of emancipatory pedagogy' have perhaps not been sufficiently mindful 
that a decisive step forward in scholarship is initially only a hypothesis - one that is evaluated by working out its implications in some detail. (Kaufmann et al, 1991, p. 87)

If one is tempted to object to Gruschka and Scheilke by identifying the concept of emancipation as the red thread that is woven through Mollenhauer's work - beginning with Education and Emancipation (1968), through Theories of the Educational Process (1972), up to Forgotten Connections (1983) and beyond - one still has the problem that Mollenhauer himself was doing little with it in the mid-1980's. If one wants to defend Mollenhauer against his critics, it is not difficult also to defend the man against himself? On the other hand, closer examination of the exchange between Scheilke, Gruschka and Mollenhauer suggests that it is not so much a matter of how the participants are understanding "emancipation" as the expectations each has regarding the relationship between pedagogy and society; about one's political positioning vis-à-vis education.

It is precisely here that the break between the generations appears; it is here that they are clearly talking past one another. If Gruschka and Scheilke understand emancipation as a sociopolitical undertaking, to which educational studies are irretrievably committed, then Mollenhauer understands emancipation as an analytical tool for use within education studies and theory. It is clear from in conversation how two generations arise in scholarship a form, at any given time, a generational unity -at the same time that the term "68er itself seems to be emerging. Mollenhauer identifies with the "unity" of the Flakhelfer generation, while Gruschka and Scheilke distance themselves from Mollenhauer's generation demarcating their own generational unity. The concept of emancipation is something that united the two generations in the first few decades after the War. And Mollenhauer's Forgotten Connections occasioned the conversation in which the disunity of the generations became clear. By the way, in the same year as this conversation the so-called Historiker-Streit (Historian's dispute) concerning fascism versus totalitarianism

How is one to answer to these questions in a simple conversational reply? In the heat of the moment, this appears as a rather unobtrusive, even overly elegant response, marked by a refusal of dogmatism. In this case, it was not that Mollenhauer - situated in a school-reform tradition within his own family - had any difficulty honoring the modest, practical gains of the emancipative orientation of the sixties and seventies. He was not, in other words, seeking to do a disservice to the achievements of his own students. It is only that he saw practice not so much in terms of his own direct actions, but, remarkably, in terms of the limited potential for change of the notion of emancipation that he had helped to form.

\section{Endnotes}

i. The author emphatically thanks his colleague Norm Friesen for the translation of this text. AA

ii. This is a compound term, consisting of "flak," a word which appeared in the English language only with the advent of WWII. Its letters were derived precisely from the type of defensive weapon whose use Mollenhauer supported, a "FLiegerAbwehrKanone," literally, pilot defence gun. Helfer, the second term, is of course, "helper."

iii. See: Bernfeld, S. (1973) Sisyphus, or The Limits of Education and (1993) The Psychology of the Infant (The International Library of Psychology: Developmental Psychology). 


\section{References}

Bude, H. (1997), Das Altern einer Generation: Die Jahrgänge 1938-1948.

Frankfurt a. M.: Suhrkamp.

Busche, J. (2007). Die 68er: Biographie einer Generation. Berlin: BVT.

Bebnowski, D. (2012). Generation und Geltung: Von den „45ern“ zur „Generation Praktikum“ - übersehene und etablierte Generationen im Vergleich. Bielefeld: transcript.

Kaufmann, H.-B./et al. (Eds.) (1991). Kontinuität und Traditionsbrüche in der Pädagogik: Ein Gespräch zwischen den Generationen. Weinheim/Basel: Beltz.

Mannheim, K. (1928). Das Problem der Generationen. In: Mannheim, K. (1964), Wissenssoziologie: Auswahl aus dem Werk (Ed. by Kurt H. Wolff). Berlin/Neuwied: Luchterhand, pp. 509-565.

Mollenhauer, K. (1968). Erziehung und Emanzipation: polemische Skizzen $\left(4^{\text {th }}\right.$ ed.). München: Juventa.

Mollenhauer, K. (1979). Aspekte einer strukturalen pädagogischen Interaktionsanalyse:

Methodologische Überlegungen zur gesellschaftlichen Formierung von Bildungsverläufen. In H. Röhrs,(Ed.),Die Erziehungswissenschaft und die Pluralität ihrer Konzepte (Festschrift für Wilhelm Flitner) (pp. 241-253). Wiesbaden: Westdeutscher Verlag,.

Pinder, W. (1926), Das Problem der Generationen in der Kunstgeschichte Europas (2nd ed.). München: Bruckner.

Winkler, M. (2002). Klaus Mollenhauer: ein pädagogisches Portrait. Weinheim/Basel: Beltz. 